\title{
ANALISIS PERILAKU PEMBELIAN OBAT-OBATAN HALAL DI PROVINSI JAWA TENGAH
}

\author{
Mochamad Edris \\ Program Studi Magister Manajemen, Fakultas Ekonomi dan Bisnis, Universitas Muria Kudus, \\ Indonesia \\ mochamad.edris@umk.ac.id
}

\begin{abstract}
ABSTRAK
Penelitian ini bertujuan untuk menganalisis perilaku pembelian dan menentukan faktor yang paling dominan mempengaruhi niat beli obat-obatan berlabel halal konsumen Muslim di Jawa Tengah. Jumlah sampel sebanyak 244 responden. Pengambilan data menggunakan kuesioner dengan teknik judgment sampling, kemudian dianalisis dengan teknik Structural Equation Modelling (SEM) menggunakan AMOS. Model Theory of Planned Behavior digunakan untuk melihat faktor-faktor yang mempengaruhi keputusan dan perilaku pembelian. Masyarakat saat ini masih belum memperhatikan label halal pada saat membeli dan atau mengkonsumsi produk obat-obatan dan makanan. Hasil penelitian diketahui bahwa norma subjektif, sikap, dan persepsi kendali perilaku memiliki pengaruh terhadap niat beli konsumen untuk membeli obat-obatan berlabel halal. Norma subjektif memiliki pengaruh yang paling dominan terhadap niat beli dan secara signifikan norma subjektif juga memiliki pengaruh terhadap sikap konsumen akan obat-obatan berlabel halal. Hasil penelitian ini berarti orang-orang penting di sekitar konsumen atau faktor lingkungan sosial terdekat seperti keluarga dan teman memiliki pengaruh yang sangat kuat dalam pembuatan keputusan pembelian konsumen. Penelitian ini memperkuat penelitian sebelumnya mengenai niat pembelian konsumen.
\end{abstract}

Kata Kunci:

Norma Subjektif, Sikap, Persepsi Kendali Perilaku, Niat Beli, Obat-obatan Halal

\begin{abstract}
This study aims to analyze purchasing behavior and to determine the most dominant factor influencing purchase intention of halal labeled medicines of Muslim consumers in Central Java. Sample of 244 respondents are used in this study. Data is collected using questionnaire with judgment sampling technique and analyzed using the Structural Equation Modeling technique using AMOS. Theory of Planned Behavior model is used to identify factors influence purchasing decision and behavior. Today's society pays little attention to the halal label when buying and or consuming medicine and food products. The results of the study found that subjective norms, attitudes, and behavioral control perceptions have an influence on consumer purchase intentions to buy halal labeled medicines. Subjective norms have the most dominant influence on purchase intentions. Furthermore, subjective norms have a significant effect on consumer attitudes toward halal labeled medicines. This results show that significant people around consumer or social environment factors such as family and friends have a strong influence in consumer purchasing decision making. This study supports the previous research on consumer purchase intention.
\end{abstract}

Keywords:

Subjective Norms, Attitude, Behavioral Control Perceptions, Purchase Intentions, Halal Labeled Medicines 


\section{PENDAHULUAN}

Sebagai negara dengan jumlah penduduk Muslim terbesar di dunia, Indonesia merupakan pasar potensial bagi industri halal dunia. Jika sebelumnya pasar produk halal dianggap terbatas dan kurang menguntungkan, saat ini produk halal telah mampu menjadi primadona yang digunakan beberapa negara untuk meningkatkan devisa. Dengan potensi pasar yang diperkirakan mencapai \$2,7 triliun secara global (World Halal Forum, 2013), dan permintaan yang tidak hanya datang dari konsumen Muslim, tampaknya menjadi motivasi bagi sejumlah Negara seperti Malaysia, Thailand, Indonesia, dan Jepang berlomba menjadi pusat produk halal atau Halal Hub (Golnaz, dkk. 2010) .

Di Indonesia kini semakin banyak pilhan produk obat-obatan berlabel halal ditawarkan oleh berbagai perusahaan obat. Masing-masing perusahaan berusaha untuk mendiferensiasikan produknya dalam upaya memunculkan keunikan dan karakteristik sehingga menimbulkan niat beli konsumen (Utama, 2004).

Model Theory Planed Behavior digunakan dalam sejumlah penelitian yang berkaitan dengan perilaku konsumen dan psikologi sosial serta digunakan sebagai kerangka teori dalam menentukan niat untuk membeli dan mengkonsumsi makanan halal.

Beberapa penelitian yang menggunakan model Model Theory Planed Behavior memperlihatkan adanya hubungan positif antara religiositas seseorang dengan perilaku konsumsi (Adi, dkk. 2014; Borzoe, Asgari. 2013; Shah Alam dan Mohamed, 2011) menunjukkan bahwa sikap, norma subyektif, dan kontrol perilaku memiliki pengaruh yang signifikkan terhadap niat untuk membeli makanan halal. Penelitian lain yang menggunakan Theory of Planed Behavior (TPB) menunjukkan bahwa sikap dan norma subjektif merupakan faktor yang signifikan mempengaruhi intensi seseorang untuk mengkonsumsi produk halal (Bonne, dkk. 2007; Lada, dkk. 2009; Soesilowati, 2018; Tarkiainen dan Sundqvist, 2005) $[3,7,12,14]$. Dengan adanya hasil-hasil penelitian tersebut, logo halal merupakan hal yang berpengaruh terhadap niat pembelian produk halal, namun demikian pada kenyataannya masih banyak masyarakat yang tidak memperdulikan 
mengenai logo halal dalam produk yang akan dikonsumsinya.

Menggunakan TPB sebagai kerangka konseptual (Liou dan Contento, 2001) mengungkapkan bahwa norma subyektif tidak signifikan terhadap niat berperilaku, sebaliknya (Lada, dkk. 2009) menemukan bahwa sikap dan norma subjektif positif berkaitan dengan niat memilih produk halal.

Penelitian ini bertujuan untuk menganalisis perilaku pembelian obat-obatan berlabel halal oleh konsumen Muslim di Jawa Tengah dengan ruang lingkup meliputi wilayah Paku Jembara, yakni daerah Pati, Kudus, Jepara dan Rembang dan Demak. Berdasarkan latar belakang penelitian maka pertanyaan utama dari penelitian ini adalah Bagaimana tiga variabel Theory of Planned Behavior norma subyektif, sikap, persepsi kendali perilaku mempengaruhi niat konsumen muslim untuk melakukan pembelian obat-obatan berlabel halal.

\section{TINJAUAN PUSTAKA}

\section{Theory of Planned Behavior}

Dengan semakin bertambahnya jumlah produsen yang hadir dipasar, menciptakan pilihan-pilihan baru untuk konsumen. Penentuan produk mana yang akan dibeli oleh konsumen akan melibatkan proses kognitif yang dimulai dari evaluasi terhadap produk tersebut hingga timbulnya niat untuk membeli, kecuali untuk pembelian impulsive (Peter dan Olson, 2010). Peneliti dan produsen biasanya menggunakan faktor niat ini untuk mengukur potensi penjualan di masa depan, namun mengukur niat bukan hal yang mudah karena niat merupakan faktor internal yang abstrak (tidak bisa dirasakan melalui panca indra). Teori perilaku terencana (theory of planned behavior) merupakan model yang umum digunakan untuk melihat faktor-faktor yang mempengaruhi keputusan dan perilaku pembelian konsumen terhadap produk tertentu. Menurut teori ini sebuah perbuatan diawali dengan niat (intention) dimana niat tersebut dipengaruhi oleh tiga faktor internal yaitu: sikap (attitude), norma subjektif (subjective norms), dan persepsi kendali perilaku (perceived behavioral control).

Pada penelitian ini, peneliti menggunakan Theory of Planned Behavior untuk mengetahui faktor apa yang memiliki pengaruh dominan terhadap niat untuk 
membeli obat-obatan berlabel halal. Landasan

berpikir yang digunakan pertama, perilaku pembelian yang dimaksud adalah perilaku yang melalui proses kognisi (bukan impulsive buying). Kedua, faktor-faktor tersebut merupakan faktor internal artinya meskipun dalam teori ekonomi klasik harga dianggap sebagai fungsi (utama) dari permintaan namun dalam penelitian ini harga tidak dilihat secara terpisah namun lebih melihat ketika harga sudah terinternalisasi ke dalam sistem kognisi konsumen dan membentuk persepsi seperti saya suka produk $\mathrm{X}$ dengan tingkat harga tersebut atau dengan harga tersebut saya (konsumen) merasa mampu/tidak mampu untuk membeli produk dan sebagainya.

\section{a. Norma Subjektif (Subjective norms)}

Norma subjektif adalah persepsi individu atas orang-orang yang penting bagi dirinya terhadap suatu objek. Jika sikap didorong dari hasil evaluasi diri sendiri, lain halnya dengan norma subjektif yang berasal dari pengaruh luar. Hal ini yang membuat perspektif sosial atau organisasi sangat berpengaruh terhadap pembentukan persepsi seorang konsumen Muslim. Semakin banyak orang yang penting bagi dirinya menganjurkan untuk membeli 158 obat-obatan berlabel halal maka dia akan cenderung memiliki niat yang lebih untuk membeli obat-obatan berlabel halal. Norma subjektif ini akan semakin kuat ketika seseorang atau konsumen berada di situasi yang lebih diktator (Venkatesh dan David, 2000).

\section{b. Persepsi Kendali Perilaku}

Variabel persepsi kendali perilaku sebagai seberapa jauh seseorang percaya atau merasa mampu untuk melakukan sesuatu (Ajzen, 1991). Variabel ini ditentukan oleh keyakinan individu mengenai kekuatan baik situasional dan faktor internal untuk memfasilitasi perilaku. Semakin seorang mempersepsikan dirinya maka akan semakin besar intensi seseorang untuk melakukan suatu perbuatan. Jika seseorang mempersepsikan dirinya memiliki sumber daya untuk membeli obat-obatan halal, maka niat untuk membeli obat-obatan dengan label halal akan semakin besar.

Beberapa penelitian yang menganalisis perilaku konsumen terhadap produk halal diantaranya: Novia dan Nurcaya (2013); dan Khalek (2014). Penelitian tersebut menggunakan tiga determinan untuk melihat 
pengaruh niat beli. Hasilnya menunjukkan bahwa kesadaran bahan dan produk halal telah dipengaruhi oleh niat membeli. Referensi Novia dan Nurcaya (2013) menggunakan dua determinan. Hasilnya menunjukkan bahwa sikap dan norma subjektif, norma subjektif berpengaruh signifikan terhadap niat beli, Referensi Khalek (2014) menggunakan tiga determinan norma subjektif, sikap, dan perilaku kontrol untuk melihat niat seseorang mengkonsumsi makanan halal. Penelitian Khalek menemukan norma subjektif, sikap, dan perilaku kontrol berpengaruh terhadap niat beli.

Penelitian tersebut di atas mengkonfirmasi adanya pengaruh positif dari ketiga faktor norma subjektif, sikap, dan persepsi kendali perilaku terhadap niat beli obat-obatan berlabel halal.

Penelitian yang dilakukan oleh Soesilowati (2018) terhadap konsumen Muslim di Banten menempatkan halal sebagai kriteria utama dalam memilih makanan. Meskipun demikian, kesadaran konsumen untuk memeriksa apakah ada jaminan halal (berupa logo halal dari LPPOM MUI) yang tercantum pada kemasan masih rendah. Konsumen menganggap jaminan halal tersebut bukan suatu hal yang krusial dan selama pedagang yang menjual produk tersebut beragama Islam maka produk tersebut sudah dianggap halal.

\section{METODE RISET}

Penelitian ini memiliki empat variabel laten dan 28 indikator. Pengumpulan data untuk melihat hubungan variabel laten dilakukan melalui kuesioner yang diadaptasi dari beberapa sumber dengan menggunakan skala Likert 1 sampe dengan 5 dimana (1) Sangat Tidak Setuju; (2) Tidak Setuju; (3) Netral; (4) Setuju; (5) Sangat Setuju. Kuesioner tersebut disebar kepada 250 mahasiswa Fakultas Ekonomi dan Bisnis Strata 1 maupun Pasca Sarjana yang berasal dari wilayah kabupaten Pati, Kudus, Jepara, Rembang dan Demak sebagai subyek penelitian. Teknik penentuan sampel menggunakan judgment sampling dikarenakan dibutuhkan responden dengan kriteria telah membeli dan mengkonsumsi obat berlabel halal yang berasal dari wilayah kabupaten Pati, Kudus, Jepara, Rembang dan Demak.

$$
\text { Setelah kuesioner disebarkan dan }
$$
diperiksa, delapan dari kuesioner yang disebar 
tidak dapat digunakan karena dalam pengisiannya, responden tidak mengisi kuesioner secara lengkap. Jumlah akhir kuesioner valid sebanyak 244. Menurut Mukhtar dan But (2012), penentuan sampel diperoleh dari 5 sampai dengan 10 dikalikan jumlah indikator. Dalam penelitian ini perhitungan sampel menjadi $8 \times 28$ Indikator $=$ 224 responden, sehingga 244 dianggap sudah mencukupi. Data yang terkumpul kemudian dianalisis dengan menggunakan Structural Equation Modeling dengan menggunakan AMOS. SEM ini sebenarnya merupakan teknik regresi yang dilakukan secara simultan dan umum digunakan untuk mengukur variabel yang abstrak.

HASIL PENELITIAN DAN PEMBAHASAN

Hasil pengujian kelayakan model persamaan struktural ini telah dilakukan modifikasi model, karena pada tahap awal model belum fit dengan cara menghubungkan antar indikator. Hasil setelah dilakukan modifikasi, nilai-nilai berada dalam rentang yang diharapkan. Evaluasi model menunjukkan dari delapan kriteria goodness of fit model 160 memenuhi kriteria dan sudah mendekati nilai kritis yang disarankan, dengan demikian merujuk pada prinsip parsimony, model secara keseluruhan dapat dikatakan telah sesuai dengan data dan dapat dianalisis lebih lanjut.

Tabel 1. Karakteristik Responden

\begin{tabular}{llcc}
\hline $\begin{array}{c}\text { Karakteristik } \\
\text { Responden }\end{array}$ & Rincian & Frekuensi & $\begin{array}{c}\text { Persen- } \\
\text { tase }\end{array}$ \\
\hline Agama & Islam & 244 & $100 \%$ \\
Jenis Kelamin & Laki-laki & 119 & $48,77 \%$ \\
Umur & Perempuan & 125 & $51,23 \%$ \\
& $20-30$ & 65 & $26.64 \%$ \\
& tahun & & \\
& $31-40$ & 145 & $59.43 \%$ \\
& tahun & & \\
Tempat & $41-50$ & 32 & $13.11 \%$ \\
tinggal & tahun & 2 & $0.82 \%$ \\
& $>50$ tahun & & \\
& Kudus & 82 & $33.61 \%$ \\
& Pati & 48 & $19.67 \%$ \\
& Rembang & 32 & $13.11 \%$ \\
& Jepara & 45 & $18.44 \%$ \\
Pendidikan & Demak & 37 & $15.16 \%$ \\
& Sarjana & 110 & $45.08 \%$ \\
& SMA/SMK & 134 & $54.92 \%$ \\
\hline \multicolumn{5}{c}{ Sumber: Data primer, 2019 diolah }
\end{tabular}

Tabel 2. Hasil Goodness of fit Model Struktural

\begin{tabular}{cccc}
$\begin{array}{c}\text { Goodness of } \\
\text { Fit Indeks }\end{array}$ & $\begin{array}{c}\text { Cut of } \\
\text { Value }\end{array}$ & Hasil & $\begin{array}{c}\text { Evaluasi } \\
\text { Model }\end{array}$ \\
\hline Chi-Square & Kecil & 120,686 & Baik \\
Probability & $\geq 0,05$ & 0,054 & Baik \\
CMIN/DF & $\leq 2,00$ & 1,911 & Baik \\
AGFI & $\geq 0,90$ & 0,950 & Baik \\
GFI & $\geq 0,90$ & 0,905 & Baik \\
CFI & $\geq 0,95$ & 0,982 & Baik \\
TLI & $\geq 0,95$ & 0,991 & Baik \\
RMSEA & $\leq 0,08$ & 0,076 & Baik \\
\hline
\end{tabular}

Sumber: Data primer, 2019 diolah 
Tabel 3. Regression Weight Structural Equation Model

\begin{tabular}{|c|c|c|c|c|c|}
\hline No & $\begin{array}{c}\text { Variabel } \\
\text { Berpengaruh }\end{array}$ & $\begin{array}{c}\text { Variabel } \\
\text { Dipengaruhi }\end{array}$ & $\begin{array}{l}\text { Nilai } \\
\text { Estimasi }\end{array}$ & $\begin{array}{c}\mathrm{T} \\
\text { hitung } \\
\text { /C.R }\end{array}$ & Sig \\
\hline 1 & $\begin{array}{l}\text { Norma_Subje } \\
\text { ktif }\end{array}$ & Sikap & .396 & 3.530 & .000 \\
\hline 2 & $\begin{array}{l}\text { Persepsi_Ken } \\
\text { dali_Perilaku }\end{array}$ & Sikap & .180 & 2.882 & .008 \\
\hline 3 & $\begin{array}{l}\text { Norma_Subje } \\
\text { ktif }\end{array}$ & Niat Beli & .131 & 2.358 & .022 \\
\hline 4 & $\begin{array}{l}\text { Persepsi_Ken } \\
\text { dali_Perilaku }\end{array}$ & Niat Beli & .127 & 2.500 & .021 \\
\hline 5 & Sikap & Niat Beli & .159 & 2.234 & .033 \\
\hline 6 & $\begin{array}{l}\text { Norma_Subje } \\
\text { ktif }\end{array}$ & $\begin{array}{l}\text { Niat Beli } \\
\text { melalui } \\
\text { sikap }\end{array}$ & .076 & 2.145 & .026 \\
\hline 7 & $\begin{array}{l}\text { Persepsi_Ken } \\
\text { dali_Perilaku }\end{array}$ & $\begin{array}{l}\text { Niat Beli } \\
\text { melalui } \\
\text { sikap }\end{array}$ & .022 & 2.075 & .032 \\
\hline
\end{tabular}

Mengacu pada hasil pengujian tahap akhir terhadap model keseluruhan, maka dapat dituliskan persamaan model matematik dalam bentuk Structural Equation Model (SEM) sebagai berikut :

$$
\begin{aligned}
& \mathrm{Y}_{1}=0,396 \mathrm{X}_{1}+0,180 \mathrm{X}_{2}+\varsigma_{1} \\
& \mathrm{Y}_{2}=0,131 \mathrm{X}_{1}+0,127 \mathrm{X}_{2}+0,159 \mathrm{Y}_{1}+\varsigma_{2} \\
& \mathrm{R}^{2}=0,296(\text { persamaan } 1) \\
& \left.\mathrm{R}^{2}=0,271 \text { (persamaan } 2\right)
\end{aligned}
$$

Nilai square multiple correlation dilihat di lampiran estimate pada group number 1default model) yang dalam statistik dikenal dengan $\mathrm{R}^{2}$ dapat dijelaskan sebagai berikut:

1) Nilai squared multiple correlation pada persamaan pertama adalah 0,296 . Nilai ini mengindikasikan bahwa 29,6\% dari variasi nilai sikap ditentukan oleh variasi nilai variabel Norma Subjektif dan Persepsi Kendali Perilaku.

2) Nilai squared multiple correlation pada persamaan kedua adalah 0,271. Nilai ini mengindikasikan bahwa $27,1 \%$ dari variasi nilai niat beli konsumen ditentukan oleh variasi nilai variabel Norma Subjektif dan Persepsi Kendali Perilaku serta sikap.

Berdasarkan pengujian diperoleh hasil, bahwa ada pengaruh signifikan Norma_Subjektif terhadap sikap konsumen Muslim di Jawa Tengah menunjukkan nilai CR sebesar 3,530 dengan probabilitas sebesar $0,000<0,05$. Ada pengaruh signifikan Persepsi Kendali Perilaku terhadap sikap konsumen Muslim di Jawa Tengah menunjukkan nilai $\mathrm{CR}$ sebesar 2,882 dengan probabilitas sebesar $0,008<0,05$. Ada pengaruh signifikan Norma Subjektif terhadap niat beli konsumen Muslim di Jawa Tengah menunjukkan nilai CR sebesar 2,358 dengan probabilitas sebesar 0,021 . Karena nilai probabilitas $=0,022<0,05$. Ada pengaruh signifikan Persepsi Kendali Perilaku terhadap niat konsumen Muslim di Jawa Tengah menunjukkan nilai $\mathrm{CR}$ sebesar 2,500 dengan 
probabilitas sebesar $0,021<0,05$. Ada pengaruh signifikan sikap konsumen terhadap niat beli konsumen Muslim di Jawa Tengah menunjukkan nilai $\mathrm{CR}$ sebesar 2,234 dengan probabilitas sebesar $0,033<0,05$. Ada pengaruh signifikan Norma Subjektif terhadap niat beli konsumen melalui sikap konsumen Muslim di Jawa Tengah menunjukkan nilai CR sebesar 2.145 dengan probabilitas sebesar $0,026<0,05$. Ada pengaruh signifikan Persepsi Kendali Perilaku terhadap niat beli konsumen melalui sikap konsumen Muslim di Jawa Tengah menunjukkan nilai CR sebesar 2.075 dengan probabilitas sebesar 0,032< 0,05 .

Hasil penelitian ini berarti orang-orang penting di sekitar konsumen atau faktor lingkungan sosial terdekat seperti keluarga dan teman memiliki pengaruh yang sangat kuat dalam pembuatan keputusan pembelian konsumen. Konsumen akan memiliki niat yang kuat untuk membeli obat-obatan berlabel halal jika di lingkungan sosialnya menyarankan untuk membeli obat-obatan halal atau konsumen melihat lingkungan sosial tersebut menggunakan obat-obatan berlabel halal.
Variabel persepsi kendali perilaku pada penelitian ini juga memiliki pengaruh yang signifikan terhadap niat beli konsumen untuk membeli obat-obatan berlabel halal. Hal ini berarti semakin konsumen merasa dirinya mampu untuk membeli obat-obatan berlabel halal maka akan semakin besar niat beli konsumen untuk membeli obatan-obatan halal. Harga dan distribusi produk merupakan dua faktor yang mempengaruhi persepsi mampu atau tidaknya konsumen. Harga jual produk yang tinggi dan produk yang langka dan sulit didapat akan membuat konsumen merasa tidak mampu untuk membeli sehingga menurunkan niat beli konsumen untuk membeli obat-obatan halal.

Sikap secara signifikan mempengaruhi intensi pembelian konsumen obat-obatan berlabel halal. Sikap yang positif menggambarkan rasa puas konsumen terhadap produk. Rasa puas tersebut tersebut timbul ketika produk yang ditawarkan dapat memenuhi bahkan melebihi ekspektasi konsumen. Obatan-obatan halal membawa dua ekspektasi konsumen yaitu dari sisi sebagai obat itu sendiri dan ekspektasi dari label halal yang digunakan. Konsumen akan melakukan 
pembelian berulang atas suatu produk

berdasarkan kualitas nyata dari produk yang ditawarkan.

\section{KESIMPULAN DAN SARAN}

Perilaku pembelian terbentuk dari proses kognisi dan dengan mengadopsi model Theory of Planned Behavior diketahui norma subjektif, persepsi kendali perilaku dan sikap memiliki pengaruh terhadap niat beli konsumen untuk membeli obat-obatan berlabel halal. Dari hasil penelitian, faktor norma subjektif memiliki pengaruh yang paling besar terhadap niat pembelian dan secara signifikan norma subjektif juga memiliki pengaruh terhadap sikap konsumen akan obat-obatan halal. Dengan mengetahui hal tersebut, produsen dapat membuat strategi pemasaran yang lebih efektif yaitu dengan membentuk persepsi positif di lingkungan sosial konsumen. Kualitas, keamanan, kesehatan dan layanan purna jual produk merupakan hal digunakan konsumen untuk mengevaluasi produk, sementara atribut berupa harga dan distribusi akan menentukan apakah konsumen merasa mampu atau tidak untuk membeli obat-obatan halal. 


\section{DAFTAR PUSTAKA}

Adi, B., Salehudin, I., \& Luthfi, B. A. (2014). Munich Personal RePEc Archive Marketing impact of halal labeling toward Indonesian muslim consumer 's behavioral intention Marketing Impact of Halal Labeling toward Indonesian Muslim Consumer 's Behavioral Intention. (54341).

Ajzen, I. (1991). The theory of planned behavior. Organizational Behavior and Human Decision Processes.

Bonne, K., Vermeir, I., Bergeaud-Blackler, F., \& Verbeke, W. (2007). Determinants of halal meat consumption in France. British Food Journal, 109(5), 367-386

Borzooei, M., \& Asgari, M. (2013). The Halal Brand Personality and its Effect on Purchase Intention. Interdisciplinary Journal of Contemporary Research in Business, 5(3), 481.

Golnaz, R., Zainalabidin, M., Mad Nasir, S., \& Eddie Chiew, F. C. (2010). Non-muslims' awareness of Halal principles and related food products in Malaysia. International Food Research Journal, $17(3), 667-674$.

Khalek, A. A. (2014). Young Consumers' Attitude towards Halal Food Outlets and JAKIM's Halal Certification in Malaysia. Procedia - Social and Behavioral Sciences, 121(September 2012), $26-34$.

Lada, S., Harvey Tanakinjal, G., \& Amin, H. (2009). Predicting intention to choose halal products using theory of reasoned action. International Journal of Islamic and Middle Eastern Finance and Management, 2(1), 66-76.

Liou, D., \& Contento, I. R. (2001). Usefulness of psychosocial theory variables in explaining fat-related dietary behavior in Chinese Americans: Association with degree of acculturation. Journal of Nutrition Education and Behavior, 33(6), 322-331

Mukhtar, A., \& Butt, M. M. (2012). Intention to choose Halal products: The role of religiosity. Journal of Islamic Marketing.

Novia Mandasari, R., \& Nurcaya, I. (2013). Pengaruh Sikap Konsumen Dan Norma Subyektif Terhadap Niat Beli Mobil Toyota Agya Di Kota Denpasar. E-Jurnal Manajemen Universitas Udayana, 2(11).

Peter, J. P., \& Olson, J. C. (2010). Consumer Behavior \& Marketing. In Dana

Soesilowati, E. (2018). Business opportunities for Halal Products in the Global Market: Muslim Consumer Behaviour and Halal food Consumption. Journal of Indonesian Social Sciences and Humanities, 3(1), 151-160.

Shah Alam, S., \& Mohamed Sayuti, N. (2011). Applying the Theory of Planned Behavior (TPB) in halal food purchasing. International Journal of Commerce and Management, 21(1), 8-20.

Tarkiainen, A., \& Sundqvist, S. (2005). Subjective norms, attitudes and intentions of Finnish consumers in buying organic food. British Food Journal, 107(11), 808-822.

Utama, G. P. (2004). THE ULTIMATE MARKETING IN Galih Prasetya Utama.

Venkatesh, V., \& Davis, F. D. (2000). Theoretical extension of the Technology Acceptance Model: Four longitudinal field studies. Management Science. 
Analisis Perilaku Pembelian Obat-Obatan Halal.... (Mochamad Edris)

World Halal Forum. (2013). (http://www.wolrdhalalforum.org/whf_intro.html) 